ISSN 1392-3196 / e-ISSN 2335-8947

Zemdirbyste-Agriculture, vol. 108, No. 4 (2021), p. 321-330

DOI 10.13080/z-a.2021.108.041

\title{
Maize response to soil properties improved with beneficial microbes, humic acid and farmyard manure application
}

\author{
Izaz HUSSAIN, Ahmad KHAN, Habib AKBAR, Zahid HUSSAIN \\ The University of Agriculture Peshawar \\ Pakhtunkhwa, Pakistan \\ E-mail: ahmad0936@yahoo.com
}

\begin{abstract}
To avoid environmental pollution, the useful and safe disposal of farmyard manure (FYM) was assessed during a two-year (2017 and 2018) field experiment using beneficial microbes (BM): 25 and $50 \mathrm{~L} \mathrm{ha}^{-1}$, humic acid (HA): 3, 6 and $9 \mathrm{~kg} \mathrm{ha}^{-1}$, and FYM: 10, 15 and $20 \mathrm{Mg} \mathrm{ha}^{-1}$ compared with a control (without BM, HA or FYM). Doubling the amount of BM from 25 to $50 \mathrm{~L} \mathrm{ha}^{-1}$ delayed phenological events of maize (Zea mays L.) by one day, decreased soil total nitrogen $\left(\mathrm{N}_{\text {tot }}\right)$ content $(12.6 \%)$ but improved soil bulk density (BD) $\left(1.25 \mathrm{Mg} \mathrm{m}^{-3}\right)$, electrical conductivity (EC) $\left(1.90 \mathrm{dS} \mathrm{m}^{-1}\right)$ and mineral $\mathrm{N}\left(\mathrm{N}_{\min }\right)$ content (33.89 $\mathrm{mg} \mathrm{kg}^{-1}$ soil). Increasing HA application from 3 to $9 \mathrm{~kg} \mathrm{ha}^{-1}$, physiological maturity of maize delayed by 2 days but increased soil EC $\left(0.11 \mathrm{dS} \mathrm{m}^{-1}\right), \mathrm{BD}(1.63 \%), \mathrm{N}_{\min }(12.94 \%)$ and decreased soil $\mathrm{N}_{\text {tot }}(34.42 \%)$ content. With the FYM level increasing from 10 to $20 \mathrm{Mg} \mathrm{ha}^{-1}$, the phenological events were delayed, but soil properties, i.e., $\mathrm{pH}\left(-0.3\right.$ unit), $\mathrm{EC}(6.66 \%), \mathrm{BD}(-5.83 \%), \mathrm{N}_{\min }(28.14 \%)$ and $\mathrm{N}_{\text {tot }}$ $(30.16 \%)$ content, were improved. Soil properties like EC and $\mathrm{N}_{\text {tot }}$ and $\mathrm{N}_{\min }$ contents showed significant positive correlation with maize leaf area, grain $\mathrm{N}$ content and grain yield. It was concluded that with addition of either $50 \mathrm{~L} \mathrm{ha}^{-1} \mathrm{BM}$ or 6-9 $\mathrm{kg} \mathrm{ha}^{-1} \mathrm{HA}, \mathrm{FYM}$ mineralization increased, growth periods prolonged and soil fertility indices improved. Thus, for improving the $\mathrm{N}_{\min }$ availability and prolonged maize phenological duration for maximizing productivity, $20 \mathrm{Mg} \mathrm{ha}^{-1} \mathrm{FYM}$ should be applied in combination with $50 \mathrm{~L} \mathrm{ha}^{-1} \mathrm{BM}$ and/or $6 \mathrm{~kg} \mathrm{ha}^{-1} \mathrm{HA}$.
\end{abstract}

Key words: decomposition, maize phenological duration, mineral nitrogen, soil properties.

\section{Introduction}

Farmyard manure (FYM) is a heterogeneous mixture of animal dung, urine and leftover materials of farm, i.e., bedding materials, residue of crops/trees/ twigs and household sweepings materials that contain plant nutrients (Satyanarayana et al., 2002). Worldwide production of FYM is around 7 billion tons with around 3.30 million tons in Pakistan (Bhattacharyya et al., 2007). The storage of such huge amount of FYM can cause environmental problems (Jiang, Yan, 2010). Therefore, the safe disposal of this huge amount of FYM is a major concern for agronomists, soil scientists and environmentalists. One of the possible options for its safe and useful usage is the recycling of such huge amount of FYM for nutrient availability in farming practices. Though the FYM is widely used as agronomic management for nutrient availability by the famer specifically in lowincome regions of the world (Khan et al., 2017; 2019); however, the bulky nature and usage in huge quantity of FYM hindered its widespread application (Muhammad et al., 2018). Similarly, the manure decomposition is slow and takes time to make the nutrients available for the plants. Thus, stimulating the FYM decomposition using soil amendment would enable the farmer to utilize the FYM more effectively with maximum benefits to soil and crop.

The benefits of FYM included enhancement in soil fertility and soil organic matter, microbiological activities (Cabilovski et al., 2014; Bello et al., 2020), improvement in soil structure for agricultural sustainability (Luo et al., 2018) as well as crop growth and production (Khan et al., 2017). FYM is a good source of nitrogen; thus, FYM application enhanced nutrient availability and plant production (Khan et al., 2015). The FYM application makes available nutrients upon decomposition, which improve crop growth and physical properties of soil (Luo et al., 2018). It is also well documented that FYM is useful for soil improvement (Khan et al., 2019), economic production and sustainable farming (Singh et al., 2015). However, the main problems of manure application included its composition, bulk application, handling and processing.

Maize is a widely distributed crop grown across the globe. It has a greater contribution toward the food stock in most developing countries, specifically it is second most important crop after wheat in Khyber Pakhtunkhwa and third after wheat (Triticum aestivum L.)

Please use the following format when citing the article:

Hussain I., Khan A., Akbar H., Hussain Z. 2021. Maize response to soil properties improved with beneficial microbes, humic acid and farmyard manure application. Zemdirbyste-Agriculture, 108 (4): 321-330. DOI 10.13080/z-a.2021.108.041 
and rice (Oryza sativa L.) in Pakistan (Ibrahim et al., 2020). Maize is used as food, feed and also as a raw material for commercial product preparation (Khan et al., 2017). In Khyber Pakhtunkhwa, the maize was planted on 0.474 million hectares having total production of 0.867 million tons with an average yield of $1827 \mathrm{~kg} \mathrm{ha}^{-1}$ as compared to the average yield of $4716 \mathrm{~kg} \mathrm{ha}^{-1}$ of Pakistan (Government of Pakistan, 2018; http://www.mnfsr.gov. $\mathrm{pk} /$ ). Comparing the average maize grain yield of Pakistan with that of the world leading maize producing countries (USA, China, Brazil, etc.), the Pakistan yield is low due to poor soil fertility and inappropriate fertilisation. Being an exhaustive crop, maize needs more nutrients as compared to other cereal crops. Thus, to improve the manure decomposition and its impact on maize, soil amendments like beneficial microbes (BM) and humic acid were used.

Beneficial microorganisms are naturally occurring microbes, which are used as inoculants to enhance soil microbial activities ultimately, soil fertility and nutrient availability thus increasing crop yield and growth (Haji et al., 2014). Integration of BM inoculums with organic/inorganic fertilisers increase nutrient availability (Kurepin et al., 2014). Bacterial inoculation increases crop production through bacterial nitrogen fixation, nutrient uptake by solubilization and hormonal activities and thus has positive effect on nutrient availability. Soil quality, plant growth and crop yield increase with the application of beneficial microbes (Haji et al., 2014). Biostimulators increase atmospheric nitrogen fixation, supress pathogen, improve the organic residue decomposition and nutrient availability for plant growth (Kurepin et al., 2014).

Humic acid (HA) is a natural producer of carbon mostly found in lignite coal in Pakistan (Hai, Mir, 1998). The microbial humification of organic matter present in soil organic matter (SOM), sediments, peat, coal, water and soil form HA (Brannon, Sommers, 1985). The HA is considered as a major SOM source and is closely related to biological, physical and chemical characteristics of soil (Khattak, Muhammad, 2008). Enhancement in soil physico-chemical and biological condition is closely related to the presence of $\mathrm{HA}$ in the soil. Model HA polymer consists of $51-57 \% \mathrm{SOC}, 0.70-1.65 \% \mathrm{~N}_{\text {tot }}$ and 0.25-0.94\% P (Brannon, Sommers, 1985). HA increases soil fertility for better plant growth, development, nutrient accumulation and net economic income. The application of HA acts as chelating agent, which not only improves the nutrient availability but can also sustains the nutrients in the soil. It is reported that, if HA is applied with fertilisers, it can enhance the crop growth and development (Bharali et al., 2017).
Soil of the study area contained less than $1 \%$ $\mathrm{SOM}$, and thus the production efficiency was low to sustain continuous cropping (Ibrahim et al., 2020). Secondly, the synthetic fertiliser application undoubtedly increased crop production (Khan et al., 2018); however, its application is not sustainable and less profitable (Muhammad et al., 2018). However, ifBM is applied along with organic fertiliser sources, it will further increase the decomposition and will be more profitable (Haji et al., 2014). In addition to BM, HA also acts as soil conditioner and has been reported to improve the soil fertility and, hence, crop production (Bharali et al., 2017). At present, an increasing trend for standard and quality agricultural production is needed in addition to quantity; thus, the organic fertilisers are used for ecological balance, lowcost cultivation, pollution free environment and quality food with no effect on human health (Khan et al., 2018).

Therefore, the current research was conducted with the aim of finding out the effect of beneficial microbes and humic acid in improving the mineral availability from FYM decomposition, soil fertility indices and their relationship with maize crop performance.

\section{Materials and methods}

Experimental site. A field experiment was conducted at Agronomy Research Farm $\left(34^{\circ} \mathrm{N}, 71^{\circ} \mathrm{E}\right)$, the University of Agriculture Peshawar, north-west Pakistan in the summer season in 2017 and repeated in 2018. The physico-chemical properties of the experimental soil were determined before sowing in 2017 using standard protocols (detailed in Soil analysis section). The soil of experimental plot was silt loam having sand (20.16\%), silt $(70.21 \%)$ and clay (9.63\%), classified as Cambisol (Siltinovic) according to WRB (2014) and as Ustochrept according to USDA (Soil Survey of Pakistan, 2007).

The initial physico-chemical properties before sowing measured on five randomly taken samples from a depth of $20 \mathrm{~cm}$ are given in Table 1 . The soil of the experimental site was alkaline with $\mathrm{pH} 8.1$, soil organic carbon (SOC) $0.53 \%$, total nitrogen $\left(\mathrm{N}_{\text {tot }}\right) 0.03 \%$, mineral nitrogen $\left(\mathrm{N}_{\min }\right) 0.68 \mathrm{mg} \mathrm{kg}^{-1}$ soil, electrical conductivity (EC) $0.41 \mathrm{dS} \mathrm{m}^{-1}$, EDTA extractable phosphorous (P) $3.87 \mathrm{mg} \mathrm{kg}^{-1}$, EDTA extractable potassium (K) $112 \mathrm{mg}$ $\mathrm{kg}^{-1}$ and soil bulk density (BD) $1.23 \mathrm{Mg} \mathrm{m}^{-3}$.

During the last five years, the experimental plots were planted with maize in summer and wheat in winter seasons with a regular maize $\rightarrow$ wheat $\rightarrow$ maize rotation. The climatic data, i.e., temperature and rainfall of the study area, is provided in Figure 1.

Table 1. Physico-chemical properties of soil, farmyard manure (FYM) and humic acid (HA) on a dry weight basis

\begin{tabular}{|c|c|c|c|c|}
\hline $\begin{array}{r}\text { Properties } \\
\end{array}$ & Unit & Soil & FYM & HA \\
\hline Organic carbon & $\%$ & 0.53 & 15.8 & 51.63 \\
\hline Total nitrogen $\left(\mathrm{N}_{\mathrm{tot}}\right)$ & $\mathrm{g} \mathrm{kg}^{-1}$ & 0.03 & 0.86 & 2.26 \\
\hline Mineral nitrogen $\left(\mathrm{N}_{\text {min }}\right)$ & $\mathrm{mg} \mathrm{kg}^{-1}$ & 0.68 & - & - \\
\hline Acidity $(\mathrm{pH})$ & - & 8.1 & 6.9 & 7.21 \\
\hline Electrical conductivity (EC) & $\mathrm{dS} \mathrm{m} \mathrm{m}^{-1}$ & 0.41 & 3.7 & 2.13 \\
\hline Phosphorous* & $\mathrm{g} \mathrm{kg}^{-1}$ & 0.39 & 2.6 & 45.4 \\
\hline Potassium* & $\mathrm{g} \mathrm{kg}^{-1}$ & 11.2 & 7.1 & 73.2 \\
\hline Bulk density (BD) & $\mathrm{Mg} \mathrm{m}^{-3}$ & 1.12 & 0.69 & 0.78 \\
\hline Sand & $\%$ & 20.16 & - & - \\
\hline Silt & $\%$ & 70.21 & - & - \\
\hline Clay & $\%$ & 9.63 & - & - \\
\hline Textural class & - & silt loam & - & - \\
\hline
\end{tabular}

* - in soil EDTA extractable 


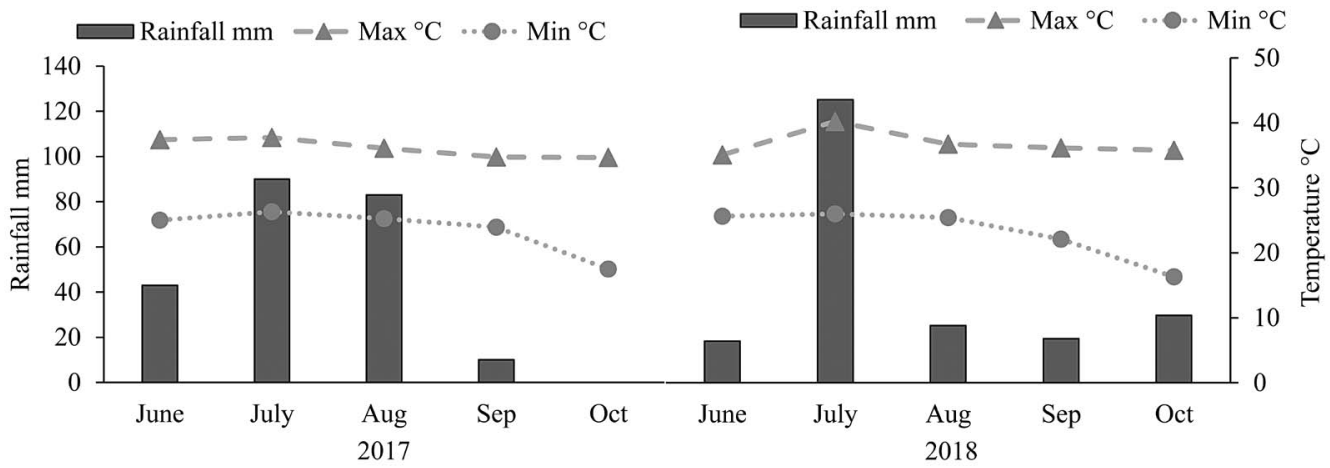

Figure 1. Rainfall and temperature maximum ( $\operatorname{Max}{ }^{\circ} \mathrm{C}$ ) and minimum (Min ${ }^{\circ} \mathrm{C}$ ) during 2017 and 2018

Materials and treatments. The experiment was conducted in a randomized complete block design(RCBD) with four replications. In the experiment, 3 factors: (1) beneficial microbes (BM), (2) humic acid (HA) and (30 farmyard manure (FYM) along with a control (without BM, HA or FYM), were used. The BM were applied as 25 or $50 \mathrm{~L} \mathrm{ha}^{-1}$, HA as 3, 6 or $9 \mathrm{~kg} \mathrm{ha}^{-1}$ and FYM as 10,15 or $20 \mathrm{Mg} \mathrm{ha}^{-1}$. The FYM was collected from the Dairy Farm, the University of Agriculture Peshawar, Pakistan and was analysed for physico-chemical properties (Table 1) using standard protocol (detailed in Soil analysis section). The analysis indicated that FYM on a dry weight basis contained $15.80 \%$ SOC, $0.86 \% \mathrm{~N}_{\text {tot }}$, pH $6.9,3.7 \mathrm{dS} \mathrm{m}^{-1}$ EC, EDTA extractable $0.26 \% \mathrm{P}$ and EDTA extractable $0.71 \% \mathrm{~K}$. The HA was applied as Humic Plus $40 \%$, a commercial product of Al-Hameed Chemicals (pvt) Ltd. (Pakistan), containing 51.63\% SOC, 2.26\% $\mathrm{N}_{\text {tot }}, \mathrm{pH} 7.21$, $2.13 \mathrm{dS} \mathrm{m}^{-1}$ EC, EDTA extractable $4.54 \% \mathrm{P}^{\text {tot }}$ and EDTA extractable $7.32 \% \mathrm{~K}$. The BM were supplied as 1 litre pack from Bioaab, a commercial product manufactured by NFRDF-NGO and Faculty of Agriculture, University of Faisalabad, Pakistan. The Bioaab consisted of Lactobacillus sp. Rhodopseudomonas sp., Actinomycetes, Cyanobacteria, Saccharomyces sp. (yeast) and molasses as media. The Bioaab purchased from the market was converted to extended solution: $1 \mathrm{~L}$ molasses was mixed with $20 \mathrm{~L}$ water in a $30 \mathrm{~L}$ plastic cane and dissolved by shaking. Then $1 \mathrm{~L}$ of Bioaab was added to the cane having dissolved molasses in water, and the cane was tightly closed and stored at room temperature for three days. The gases were released once during $24 \mathrm{~h}$ by opening the lid of the cane, and the extended solution was used for field application.

Preparation of treatments and their application. The experimental plots of $4 \times 4.5 \mathrm{~m}$ were prepared and separated with small bund (embarkment) of 5-7 cm height. The FYM was added to the soil as per proposed rates on a dry weight basis, whereas the quantified HA as per proposed rate was mixed with $1 \mathrm{~kg}$ soil per plot and sprinkled on the respective plots. The quantified extended Bioaab solution as per proposed rates was mixed with $1 \mathrm{~L}$ of distilled water per plot, well shaken before application and sprayed as saturated liquid on the soil to cover the entire plot area, where FYM and HA had been already applied. To incorporate all these treatments materials to a depth of $15 \mathrm{~cm}$, after application of the treatments and one month before sowing the plots were ploughed single time with a common field cultivator. The application of BM, HA and FYM was carried out about one month before sowing each year. For proper and effective decomposition of treatments and to maintain plots at proper field capacity level before sowing of crop in each year, two irrigations: $1^{\text {st }}$ after 10 days and $2^{\text {nd }}$ after 20 days of treatments incorporation, were made.

Field operations and methodology. Field was ploughed two times using a common field cultivator after one month of treatments incorporation at proper field capacity level during each year for seed bed preparation. The field cultivator was followed by a rotavator in the respective plots for proper seed bed development. The plots were rebuilt and separated with $10-15 \mathrm{~cm}$ high and $30 \mathrm{~cm}$ wide bunds between two plots; however, the replication-to-replication distance was $1 \mathrm{~m}$. Maize (Zea mays L., cultivar 'Azam') was sown at a seed rate of $30 \mathrm{~kg} \mathrm{ha}^{-1}$ in plots of $18 \mathrm{~m}^{-2}$ having 6 rows of $4 \mathrm{~m}$ length and spaced $75 \mathrm{~cm}$. Maize sowing was made on July 8, 2017 for the $1^{\text {st }}$ year and July 7, 2018 for the $2^{\text {nd }}$ year on the same plots with the same treatments. However, wheat was grown between two maize crops and provided with recommended amount of $120 \mathrm{~kg} \mathrm{ha}^{-1} \mathrm{~N}$ and $90 \mathrm{~kg} \mathrm{ha}^{-1} \mathrm{P}$ as a gap crop. Basal dose of $90 \mathrm{~kg} \mathrm{ha}^{-1} \mathrm{~N}_{\text {min }}$ was applied in three equal splits, i.e., $1 / 3$ each at first, third and fourth irrigation, along with a basal dose of $60 \mathrm{~kg} \mathrm{ha}^{-1} \mathrm{P}$ at the time of sowing to all plots. Field was irrigated six times both in 2017 and 2018 as flood irrigation at critical stages: after emergence, three leaf stage, knee height, tasselling/ silking, grain development and grain filling. Weeds were controlled manually by hoeing after $2^{\text {nd }}$ irrigation, and no herbicides were used. However, shoot borers were controlled through Furadan (a.i. carbofuran 3\%) applied at a rate of $20 \mathrm{~kg} \mathrm{ha}^{-1}$ after $2^{\text {nd }}$ irrigation, i.e., in three leaves stage.

Observations and measurements. Composite soil samples were collected from the experimental field (20 cm depth) before planting maize in 2017. However, three samples were made from $20 \mathrm{~cm}$ depth in each plot at tasselling stage (only for $\mathrm{N}_{\text {mi }}$ determination) as well as after maize harvesting in 2017 and 2018, composited again (same established plots in 2017 and 2018), cleaned, ground to $2 \mathrm{~mm}$ mesh size and stored for determination of soil physico-chemical properties. Samples were also collected from FYM and HA and analysed for C, N, P and $\mathrm{K}$ content as well as $\mathrm{pH}$ and $\mathrm{EC}$.

Phenological observations. Days to emergence, tasselling, silking and physiological maturity were counted as the days difference between sowing date and respective stage, when around $70 \%$ of plants attained the respective stage. Loss of green colour of leaves/cobs was considered criteria for physiological maturity.

Soil analysis. For determination of soil properties, soil samples made prior to experiment and/ or after maize harvest were used. Soil water suspension 
(1:5) was prepared by taking $10 \mathrm{~g}$ of dry soil and $50 \mathrm{ml}$ of distilled water. The suspension was shaken for $1 \mathrm{~h}$ on mechanical shaker, left for $30 \mathrm{~min}$ and then filtered. The filtrate was used for determination of soil acidity (pH) following Mclean (1983) method using $\mathrm{pH}$ meter calibration with 4 and 7 buffers. Soil core No. $42\left(100 \mathrm{~cm}^{-3}\right)$ was driven in soil to a depth of $20 \mathrm{~cm}$ after clearing the topsoil surface and carefully dug out to avoid compaction of soil block in soil core. The soil extended beyond the core side was removed carefully, the soil of the core was oven died at $105^{\circ} \mathrm{C}$ for $24 \mathrm{~h}$ and soil bulk density (BD) was calculated using formula:

$\mathrm{BD}=$ soil dry weight / volume of core.

The soil electrical conductivity (EC) was also determined using the same soil suspension with the help of soil EC meter (Rhoades, 1996).

The soil mineral nitrogen $\left(\mathrm{N}_{\text {in }}\right)$ content was determined following the steam distillation procedure as reported by Keeney and Nelson (1983). Briefly, $10 \mathrm{~g}$ of fresh soil was extracted with $100 \mathrm{ml}$ of $1 \mathrm{M} \mathrm{KCl}$ solution by shaking on mechanical shaker for $1 \mathrm{~h}$. The suspension was allowed to settle down until clear liquid supernatant and filtered. Thereafter, $0.2 \mathrm{~g}$ of $\mathrm{MgO}$ and Devarda's alloy were added to $15-20 \mathrm{ml}$ of aliquot of soil solution in distillation apparatus, and the distillate was collected in beaker having $5 \mathrm{ml} \mathrm{B}(\mathrm{OH})_{3}$ mixed indictor and titrated against $0.005 \mathrm{~N} \mathrm{HCl}$. The $\mathrm{N}_{\text {min }}$ content $\left(\mathrm{mg} \mathrm{g}^{-1}\right.$ soil) was calculated using formula:

$$
\mathrm{N}_{\text {min }}=\frac{(\mathrm{S}-\mathrm{B}) \times \mathrm{N} \times 0.014 \times \text { extract total volume }}{\text { dry sample } \mathrm{wt} \times \text { volume taken }} \times 10^{6} \text {. }
$$

The soil total nitrogen $\left(\mathrm{N}_{\text {tot }}\right)$ content was determined as per the procedure of Bremner and Mulvaney (1983). Briefly, $0.5 \mathrm{~g}$ of soil and/or 0.2 of grain fodder was digested with digestion mixture and $3 \mathrm{ml} \mathrm{H}_{2} \mathrm{SO}_{4}$ at $350^{\circ} \mathrm{C}$. The digest was used for soil $\mathrm{N}_{\text {tot }}$ using $40 \% \mathrm{NaOH}$ and $4 \% \mathrm{~B}(\mathrm{OH})_{3}$ solution in device Kjelflex K-360 (BUCHI Switzerland Ltd.) and titrated with $0.1 \mathrm{~N} \mathrm{HCl}$ solution; $\mathrm{N}$ reading (in \%) was noted directly from the tool of automatic titration Titrano plus (BUCHI Switzerland Ltd.) attached to Kjelflex K-360 Distillation Unit.
Statistical analysis. The data was analysed as per the procedure of RCBD (Jan et al., 2009). Means were compared using least significant difference (LSD) test at $P \leq 0.05$ upon significant $F$-test. The Pearson correlation analysis was carried out to understand the positive and negative relationship of soil properties with maize parameters. The statistical analysis was carried out using software Statistix, version 8.1 (Informer Technologies Inc.) and illustration by Sigma Plot, version 14 (Systat Software Inc., USA).

\section{Results}

Phenological duration of maize crop. The application of BM had no effect on days to emergence but significantly delayed tasselling, silking and physiological maturity of maize by one day based on two years data (Table 2, Figure 2). Similarly, the HA application had no significant effect on days to emergence, tasselling and silking but delayed the physiological maturity of maize by one day both in 2017 and 2018. The application of $15 \mathrm{Mg} \mathrm{ha}^{-1}$ FYM delayed days to emergence (7 days) both in 2017 and 2018 as compared to the enhanced emergence (6 days) in plots having $20 \mathrm{Mg} \mathrm{ha}^{-1} \mathrm{FYM}$. However, the application of $20 \mathrm{Mg} \mathrm{ha}^{-1}$ FYM took more days to tasselling $(53,55$ days), silking $(58,59$ days) and physiological maturity (100, 100 days) of maize in 2017 and 2018, respectively. This indicates that doubling the amount of manure from 10 to $20 \mathrm{Mg} \mathrm{ha}^{-1} \mathrm{FYM}$ delayed the tasselling in maize by 4 days, days to silking by 2 days, and physiological maturity by 2 days averaged over two years data.

Prolonged emergence (by 1 and 1 days), silking (by 2 and 5 days), tasselling (by 3 and 5 days) and physiological maturity (by 4 and 4 days) during 2017 and 2018 , respectively was noted in treated plots compared to the control (Figure 2).

Table 2. Means square errors with significance of DTE (days to emergence), DTT (days to tasselling), DTS (days to silking) and DTM (days to physiological maturity) of maize and soil properties during 2017 and 2018

\begin{tabular}{|c|c|c|c|c|c|c|c|c|c|c|}
\hline Source of variation & $\mathrm{df}$ & DTE & DTT & DTS & DTM & $\mathrm{pH}$ & $\mathrm{EC}$ & $\mathrm{BD}$ & $\mathrm{N}_{\mathrm{t}}$ & $\mathrm{N}_{\min }$ \\
\hline Year $(Y)$ & 1 & $0.32 \mathrm{~ns}$ & $67.9^{* *}$ & $30.54 *$ & $27.5 \mathrm{~ns}$ & $0.01 \mathrm{~ns}$ & $0.14^{*}$ & $0.006^{*}$ & $0.006 \mathrm{~ns}$ & $65.47 *$ \\
\hline Reps (Y) & 4 & 0.46 & 2.0 & $1.86 \mathrm{~ns}$ & $0.5 \mathrm{~ns}$ & $0.01 \mathrm{~ns}$ & 0.01 & 0.001 & 0.001 & 5.58 \\
\hline Treatments & 18 & $12.44 * *$ & $129.3 * *$ & $79.49 * *$ & $78.1 * *$ & $1.12 * *$ & $0.45 * *$ & $0.054 * *$ & $0.798 * *$ & $798.05 * *$ \\
\hline $\mathrm{C} v s \mathrm{R}$ & (1) & $11.26^{* *}$ & $63.7 * *$ & $67.08 * *$ & $85.1 * *$ & $0.73 * *$ & $0.30 * *$ & $0.064 * *$ & $0.599 * *$ & $659.46^{* *}$ \\
\hline $\mathrm{BM}$ & (1) & $0.15 \mathrm{~ns}$ & $25.0 * *$ & $11.34^{*}$ & $29.0 * *$ & $0.02 \mathrm{~ns}$ & $0.18 * *$ & $0.008 * *$ & $0.062 * *$ & $108.58 * *$ \\
\hline HA & (2) & $0.59 \mathrm{~ns}$ & $3.1 \mathrm{~ns}$ & $5.45 \mathrm{~ns}$ & $20.3 * *$ & $0.01 \mathrm{~ns}$ & $0.12 * *$ & $0.001 \mathrm{~ns}$ & $0.468 * *$ & $152.53 * *$ \\
\hline FYM & (2) & $7.34 * *$ & $136.3 * *$ & $62.95 * *$ & $34.1 * *$ & $1.15^{* *}$ & $0.26^{* *}$ & $0.039 * *$ & $0.361 * *$ & $605.83 * *$ \\
\hline $\mathrm{BM} \times \mathrm{HA}$ & (2) & $0.26 \mathrm{~ns}$ & $2.1 \mathrm{~ns}$ & $3.90 \mathrm{~ns}$ & $0.5 \mathrm{~ns}$ & $0.07 *$ & $0.01 \mathrm{~ns}$ & $0.001 \mathrm{~ns}$ & $0.007 \mathrm{~ns}$ & $20.83^{*}$ \\
\hline $\mathrm{BM} \times \mathrm{FYM}$ & (2) & $0.73 \mathrm{~ns}$ & $1.2 \mathrm{~ns}$ & $1.45 \mathrm{~ns}$ & $0.1 \mathrm{~ns}$ & $0.03 \mathrm{~ns}$ & $0.03 \mathrm{~ns}$ & $0.001 \mathrm{~ns}$ & $0.010^{*}$ & $14.82 *$ \\
\hline $\mathrm{HA} \times \mathrm{FYM}$ & (4) & $1.09 \mathrm{~ns}$ & $1.8 \mathrm{~ns}$ & $2.87 \mathrm{~ns}$ & $1.1 \mathrm{~ns}$ & $0.01 \mathrm{~ns}$ & $0.01 \mathrm{~ns}$ & $0.001 \mathrm{~ns}$ & $0.008 *$ & $7.11 \mathrm{~ns}$ \\
\hline $\mathrm{BM} \times \mathrm{HA} \times \mathrm{FYM}$ & (4) & $0.93 \mathrm{~ns}$ & $1.6 \mathrm{~ns}$ & $0.26 \mathrm{~ns}$ & $1.4 \mathrm{~ns}$ & $0.02 \mathrm{~ns}$ & $0.01 \mathrm{~ns}$ & $0.001 \mathrm{~ns}$ & $0.003 \mathrm{~ns}$ & $2.42 \mathrm{~ns}$ \\
\hline $\mathrm{Y} \times$ treatments & 18 & $0.54 \mathrm{~ns}$ & $2.2 \mathrm{~ns}$ & $1.15 \mathrm{~ns}$ & $1.0 \mathrm{~ns}$ & $0.02 \mathrm{~ns}$ & $0.01 \mathrm{~ns}$ & $0.001 \mathrm{~ns}$ & $0.002 \mathrm{~ns}$ & $2.01 \mathrm{~ns}$ \\
\hline $\mathrm{Y} \times \mathrm{C} v s \mathrm{R}$ & (1) & $0.50 \mathrm{~ns}$ & $13.1 \mathrm{~ns}$ & $4.59 \mathrm{~ns}$ & $0.2 \mathrm{~ns}$ & $0.01 \mathrm{~ns}$ & $0.01 \mathrm{~ns}$ & $0.001 \mathrm{~ns}$ & $0.001 \mathrm{~ns}$ & $3.64 \mathrm{~ns}$ \\
\hline $\mathrm{Y} \times \mathrm{BM}$ & (1) & $0.59 \mathrm{~ns}$ & $0.3 \mathrm{~ns}$ & $1.56 \mathrm{~ns}$ & $3.0^{*}$ & $0.01 \mathrm{~ns}$ & $0.02 \mathrm{~ns}$ & 0.003 & 0.001 & $1.56 \mathrm{~ns}$ \\
\hline $\mathrm{Y} \times \mathrm{HA}$ & (2) & $0.04 \mathrm{~ns}$ & $0.6 \mathrm{~ns}$ & $1.40 \mathrm{~ns}$ & $0.5 \mathrm{~ns}$ & $0.06^{*}$ & $0.01 \mathrm{~ns}$ & $0.001 \mathrm{~ns}$ & 0.006 & $1.50 \mathrm{~ns}$ \\
\hline $\mathrm{Y} \times \mathrm{FYM}$ & (2) & $1.18 \mathrm{~ns}$ & $0.7 \mathrm{~ns}$ & $1.68 \mathrm{~ns}$ & $1.2 \mathrm{~ns}$ & $0.04 \mathrm{~ns}$ & $0.01 \mathrm{~ns}$ & $0.003 \mathrm{~ns}$ & $0.004 \mathrm{~ns}$ & $2.96 \mathrm{~ns}$ \\
\hline $\mathrm{Y} \times \mathrm{BM} \times \mathrm{HA}$ & (2) & $0.59 \mathrm{~ns}$ & $1.0 \mathrm{~ns}$ & $1.51 \mathrm{~ns}$ & $0.3 \mathrm{~ns}$ & $0.01 \mathrm{~ns}$ & $0.01 \mathrm{~ns}$ & $0.003 \mathrm{~ns}$ & $0.004 \mathrm{~ns}$ & $0.03 \mathrm{~ns}$ \\
\hline $\mathrm{Y} \times \mathrm{BM} \times \mathrm{FYM}$ & (2) & $0.23 \mathrm{~ns}$ & $1.4 \mathrm{~ns}$ & $0.40 \mathrm{~ns}$ & $2.6^{*}$ & $0.01 \mathrm{~ns}$ & $0.01 \mathrm{~ns}$ & $0.001 \mathrm{~ns}$ & $0.001 \mathrm{~ns}$ & $3.14 \mathrm{~ns}$ \\
\hline $\mathrm{Y} \times \mathrm{HA} \times \mathrm{FYM}$ & (4) & $0.81 \mathrm{~ns}$ & $2.2 \mathrm{~ns}$ & $0.29 \mathrm{~ns}$ & $0.3 \mathrm{~ns}$ & $0.01 \mathrm{~ns}$ & $0.01 \mathrm{~ns}$ & $0.001 \mathrm{~ns}$ & $0.001 \mathrm{~ns}$ & $1.11 \mathrm{~ns}$ \\
\hline $\mathrm{Y} \times \mathrm{BM} \times \mathrm{HA} \times \mathrm{FYM}$ & (4) & $0.31 \mathrm{~ns}$ & $2.4 \mathrm{~ns}$ & $0.84 \mathrm{~ns}$ & $1.1 \mathrm{~ns}$ & $0.01 \mathrm{~ns}$ & $0.01 \mathrm{~ns}$ & $0.001 \mathrm{~ns}$ & $0.001 \mathrm{~ns}$ & $2.82 \mathrm{~ns}$ \\
\hline Error & 72 & 0.53 & 6.3 & 2.63 & 0.6 & 0.02 & 0.01 & $0.002 \mathrm{~ns}$ & 0.003 & $4.58 \mathrm{~ns}$ \\
\hline $\mathrm{CV} \%$ & & 10.90 & 4.8 & 2.90 & 0.78 & 1.6 & 5.38 & 3.42 & 7.02 & 6.62 \\
\hline
\end{tabular}

$\mathrm{C}$ vs $\mathrm{R}$ - control vs rest treatments, BM - beneficial microbes, HA - humic acid, FYM - farmyard manure; df - degree of freedom; $\mathrm{EC}-$ electrical conductivity, $\mathrm{BD}$ - bulk density; *, ** - significant at $p \leq 0.05$ and $p \leq 0.01$, ns - not significant 


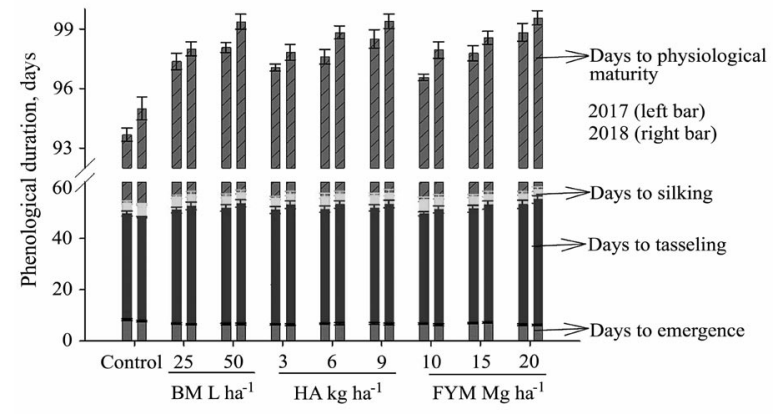

Note. The vertical bars denote standard errors of the mean.

Figure 2. Maize phenological duration in response to beneficial microbes (BM), humic acid (HA) and farmyard manure (FYM) during 2017 and 2018

The interaction between year, HA and FYM (Table 2, Figure 3) indicated that, when $3 \mathrm{~kg} \mathrm{ha}^{-1} \mathrm{HA}$ was applied, increasing the FYM level delayed the days to silking of maize both in 2017 and 2018. However, with application of HA greater than $3 \mathrm{~kg} \mathrm{ha}^{-1}$, the increased FYM had no significant differences for days to silking.

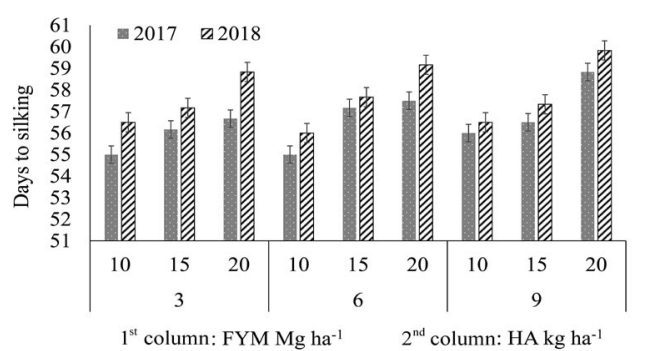

Note. The vertical bars denote standard errors of the mean.

Figure 3. The interaction of days to silking of maize for farmyard manure (FYM) and humic acid (HA) during 2017 and 2018
The interactive response of year, BM and HA interaction (Table 2, Figure 4) showed that days to physiological maturity increased with increasing level of HA in 2017 and in 2018 across both levels of BM. However, the increases in physiological maturity in the $2^{\text {nd }}$ year was prominent with $50 \mathrm{~L} \mathrm{ha}^{-1}$ over $25 \mathrm{~L} \mathrm{ha}^{-1}$ as compared to the $1^{\text {st }}$ year of cultivation.

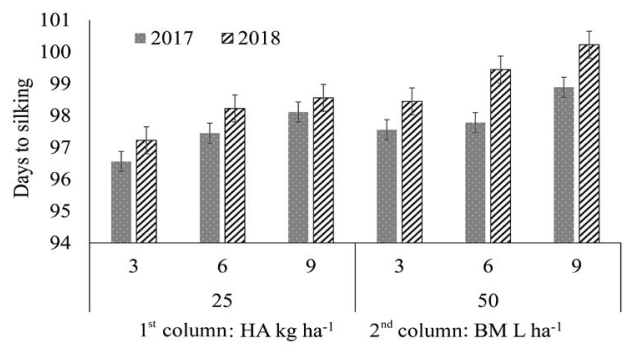

Note. The vertical bars denote standard errors of the mean.

Figure 4. The interaction of days to maturity of maize for humic acid (HA) and beneficial microbes (BM) during 2017 and 2018

Soil acidity $(\boldsymbol{p H})$ ranged from $7.7\left(20 \mathrm{Mg} \mathrm{ha}^{-1}\right.$ FYM) to 8.0 (10 $\mathrm{Mg} \mathrm{ha}^{-1}$ FYM) both in 2017 and 2018 . However, the differences for soil $\mathrm{pH}$ recorded in 2017 for 10 and $15 \mathrm{Mg} \mathrm{ha}^{-1} \mathrm{FYM}$ were not significant (Tables 2 and 3). This indicates that increasing FYM from 10 to $20 \mathrm{Mg} \mathrm{ha}^{-1}$ the soil $\mathrm{pH}$ increased by $4 \%$ both in 2017 and 2018.

The treated plots had higher soil $\mathrm{pH}$ (7.9) than control plots (7.6). Interaction between BM and HA showed that 25 or $50 \mathrm{~L} \mathrm{ha}^{-1} \mathrm{BM}$ application had no effect with increasing the HA level from 3 to $6 \mathrm{~kg} \mathrm{ha}^{-1}$ (Table 2, Figure 5). However, the $25 \mathrm{~L} \mathrm{ha}^{-1} \mathrm{BM}$ significantly lowered the soil $\mathrm{pH}$ compared to the $50 \mathrm{~L} \mathrm{ha}^{-1} \mathrm{BM}$ at $9 \mathrm{~kg} \mathrm{ha}^{-1} \mathrm{HA}$ application.

Table 3. Soil acidity $(\mathrm{pH})$, electrical conductivity $(\mathrm{EC})$, bulk density $(\mathrm{BD})$, total $\left(\mathrm{N}_{\text {tot }}\right)$ and mineral $\left(\mathrm{N}_{\text {min }}\right)$ nitrogen in response to beneficial microbes $\left(\mathrm{BM}, \mathrm{L} \mathrm{ha}^{-1}\right)$, humic acid $\left(\mathrm{HA}, \mathrm{kg} \mathrm{ha}^{-1}\right)$ and farmyard manure $\left(\mathrm{FYM}, \mathrm{Mg}^{\min } \mathrm{ha}^{-1}\right)$ during 2017 and 2018

\begin{tabular}{|c|c|c|c|c|c|}
\hline Treatment & $\mathrm{pH}$ & 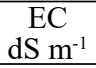 & $\begin{array}{c}\mathrm{BD} \\
\mathrm{Mg} \mathrm{m}^{-3}\end{array}$ & $\begin{array}{c}\mathrm{N}_{\text {tot }} \\
\mathrm{g} \mathrm{kg}^{-1} \text { soil }\end{array}$ & $\begin{array}{c}\mathrm{N}_{\min } \\
\mathrm{mg} \mathrm{kg}^{-1} \text { soil }\end{array}$ \\
\hline \multicolumn{6}{|c|}{2017} \\
\hline $25 \mathrm{BM}$ & $7.9 \mathrm{a}$ & $.80 \mathrm{~b}$ & $1.23 \mathrm{~b}$ & $0.80 \mathrm{a}$ & $31.00 \mathrm{~b}$ \\
\hline $50 \mathrm{BM}$ & $7.8 \mathrm{a}$ & $1.90 \mathrm{a}$ & $1.25 \mathrm{a}$ & $0.71 \mathrm{~b}$ & $33.22 \mathrm{a}$ \\
\hline Significance & ns & $*$ & $*$ & $*$ & $* *$ \\
\hline $3 \mathrm{HA}$ & $7.8 \mathrm{a}$ & $.80 \mathrm{~b}$ & 1.23 & $0.80 \mathrm{a}$ & $29.70 \mathrm{c}$ \\
\hline $6 \mathrm{HA}$ & $7.9 \mathrm{a}$ & $.83 \mathrm{a}$ & 1.24 & $0.80 \mathrm{a}$ & $32.64 \mathrm{~b}$ \\
\hline \multirow[b]{2}{*}{$\mathrm{LSD}_{0.05}$} & $7.9 \mathrm{a}$ & $1.90 \mathrm{a}$ & 1.25 & $0.61 \mathrm{~b}$ & $34.00 \mathrm{a}$ \\
\hline & ns & 0.07 & $\mathrm{Ns}$ & 0.03 & 1.32 \\
\hline $10 \mathrm{FYM}$ & $8.0 \mathrm{a}$ & $1.70 \mathrm{~b}$ & $.26 \mathrm{~b}$ & $0.63 \mathrm{c}$ & $27.70 \mathrm{c}$ \\
\hline $15 \mathrm{FYM}$ & $8.0 \mathrm{a}$ & $1.83 \mathrm{a}$ & $.23 \mathrm{a}$ & $0.75 \mathrm{~b}$ & $33.33 \mathrm{~b}$ \\
\hline $20 \mathrm{FYM}$ & $7.7 \mathrm{~b}$ & $1.90 \mathrm{a}$ & $1.22 \mathrm{a}$ & $0.81 \mathrm{a}$ & $35.20 \mathrm{a}$ \\
\hline $\mathrm{LSD}_{0.05}$ & 0.10 & 0.07 & 0.03 & 0.03 & 1.32 \\
\hline Control & $7.6 \mathrm{~b}$ & $1.62 \mathrm{~b}$ & $1.12 \mathrm{~b}$ & $0.41 \mathrm{~b}$ & $22.12 \mathrm{~b}$ \\
\hline Treated plots & $7.9 \mathrm{a}$ & $.81 \mathrm{a}$ & $.2 \overline{2} \mathrm{a}$ & $0.73 \mathrm{a}$ & $32.09 \mathrm{a}$ \\
\hline \multirow[t]{2}{*}{ Significance } & $* *$ & $* *$ & $* *$ & $* *$ & $* *$ \\
\hline & \multicolumn{5}{|c|}{2018} \\
\hline $25 \mathrm{BM}$ & $7.9 \mathrm{a}$ & $.91 \mathrm{a}$ & $.22 \mathrm{a}$ & $0.80 \mathrm{a}$ & $32.81 \mathrm{~b}$ \\
\hline $50 \mathrm{BM}$ & $7.9 \mathrm{a}$ & $.90 \mathrm{a}$ & $.23 \mathrm{~b}$ & $0.72 \mathrm{~b}$ & $34.60 \mathrm{a}$ \\
\hline Significance & ns & $*$ & $*$ & $* *$ & $* *$ \\
\hline $3 \mathrm{HA}$ & $7.9 \mathrm{a}$ & $.82 \mathrm{~b}$ & .22 & $0.84 \mathrm{a}$ & $31.53 \mathrm{~b}$ \\
\hline $6 \mathrm{HA}$ & $7.9 \mathrm{ab}$ & $.90 \mathrm{a}$ & $1.2 \overline{4}$ & $0.80 \mathrm{~b}$ & $34.44 \mathrm{a}$ \\
\hline $9 \mathrm{HA}$ & $7.8 \mathrm{~b}$ & $1.94 \mathrm{a}$ & 1.22 & $0.61 \mathrm{c}$ & $35.12 \mathrm{a}$ \\
\hline $\mathrm{LSD}_{0.05}$ & ns & 0.06 & $\mathrm{Ns}$ & 0.03 & 1.65 \\
\hline 10 FYM & $8.0 \mathrm{a}$ & $1.80 \mathrm{~b}$ & $.27 \mathrm{c}$ & $0.62 \mathrm{c}$ & $29.00 \mathrm{~b}$ \\
\hline 15 FYM & $7.9 \mathrm{~b}$ & $1.90 \mathrm{a}$ & $1.23 \mathrm{~b}$ & $0.80 \mathrm{~b}$ & $34.64 \mathrm{~b}$ \\
\hline 20 FYM & $7.7 \mathrm{c}$ & $2.00 \mathrm{a}$ & $1.18 \mathrm{a}$ & $0.84 \mathrm{a}$ & $37.50 \mathrm{a}$ \\
\hline $\mathrm{LSD}_{0.05}$ & 0.06 & 0.06 & 0.02 & 0.03 & 1.65 \\
\hline Control & $7.6 \mathrm{~b}$ & $1.62 \mathrm{~b}$ & $1.12 \mathrm{~b}$ & $0.41 \mathrm{~b}$ & $22.12 \mathrm{~b}$ \\
\hline Treated plots & $7.9 \mathrm{a}$ & $1.89 \mathrm{a}$ & $1.22 \mathrm{a}$ & $0.75 \mathrm{a}$ & $33.69 \mathrm{a}$ \\
\hline Significance & $* *$ & $* *$ & $* *$ & $* *$ & $* *$ \\
\hline
\end{tabular}

Note. Means of the same category followed by different letters are significantly different from each other at $p \leq 0.05$ using LSD test; *, ** - significant at $p \leq 0.05$ and $p \leq 0.01, \mathrm{~ns}-$ not significant. 

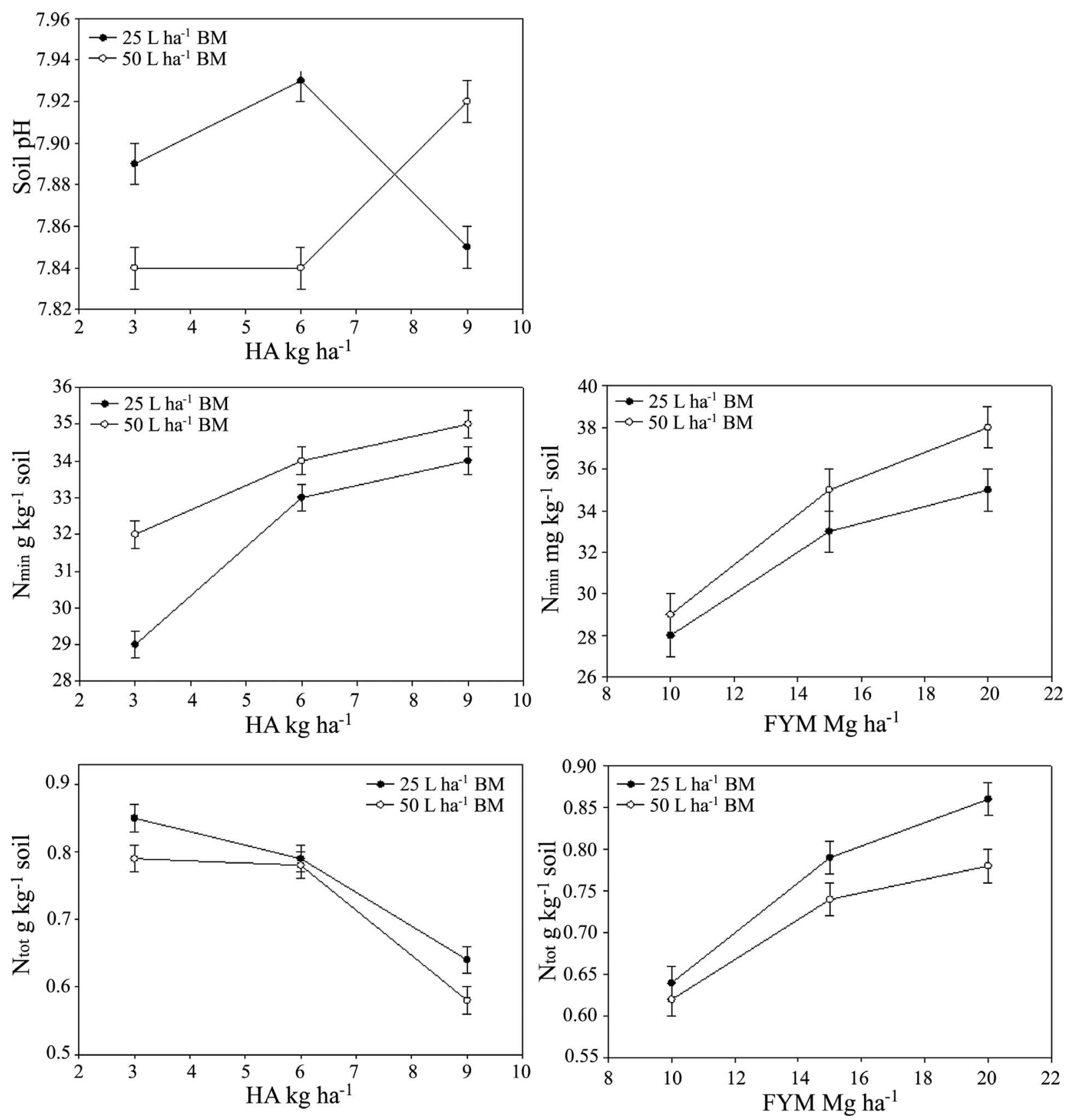

Note. The vertical bars are standard errors of the mean.

Figure 5. The interactive response of soil acidity $(\mathrm{pH})$, mineral $\left(\mathrm{N}_{\min }\right)$ and total $\left(\mathrm{N}_{\text {tot }}\right)$ nitrogen content for beneficial microbes (BM) and humic acid (HA) and BM and farmyard manure (FYM) interaction averaged over 2017 and 2018

Similarly, the interaction between year and HA showed that low level of HA was effective in controlling the soil $\mathrm{pH}$ in 2017, whereas in 2018, the high level of HA was more effective (Tables 2 and 3 ).

Soil bulk density (BD) was significantly lower in $2018\left(1.20 \mathrm{Mg} \mathrm{m}^{-3}\right)$ as compared to $2017\left(1.25 \mathrm{Mg} \mathrm{m}^{-3}\right)$ (Tables 2 and 3). The soil BD ranged from 1.25 to $1.23 \mathrm{Mg}$ $\mathrm{m}^{-3}$ with increasing the BM from 25 to $50 \mathrm{~L} \mathrm{ha}^{-1}$; however, BM had no effect on soil BD during 2018. Similarly, the application of $20 \mathrm{Mg} \mathrm{ha}^{-1} \mathrm{FYM}$ significantly lowered the soil BD over the low level of FYM. With the FYM level increasing from 10 to $20 \mathrm{Mg} \mathrm{ha}^{-1}$, the soil BD significantly decreased from 1.26 to $1.22 \mathrm{Mg} \mathrm{m}^{-3}$ in 2017 and from 1.27 to $1.18 \mathrm{Mg} \mathrm{m}^{-3}$ in 2018 . This showed that FYM had greater effect in 2018 as compared to 2017 . This indicates that increasing FYM from 10 to $20 \mathrm{Mg} \mathrm{ha}^{-1}$ decreased soil BD by $3.28 \%$ in 2017 as compared to $7.63 \%$ in 2018 . Fertilised plots had higher soil BD $\left(1.22 \mathrm{Mg} \mathrm{m}^{-3}\right)$ than control plots $\left(1.12 \mathrm{Mg} \mathrm{m}^{-3}\right)$.

Soil electrical conductivity $(\boldsymbol{E C})$ indicates that the EC was improved in $2018\left(1.89 \mathrm{dS} \mathrm{m}^{-1}\right)$ as compared to $2017\left(1.81 \mathrm{dS} \mathrm{m}^{-1}\right)$ showing an increase of $5.55 \%$ (Tables 2 and 3). When the BM level doubled from 25 to $50 \mathrm{~L} \mathrm{ha}^{-1}$, the soil EC increased from 1.76 to $1.87 \mathrm{dS}$ $\mathrm{m}^{-1}$ in 2017 and from 1.86 to $1.91 \mathrm{dS} \mathrm{m}^{-1}$ in 2018 . The application of HA level increasing from 3 to $9 \mathrm{~kg} \mathrm{ha}^{-1}$ soil EC significantly increased from 1.80 to $1.90 \mathrm{dS} \mathrm{m}^{-1}$ in 2017 and from 1.82 to $1.94 \mathrm{dS} \mathrm{m}^{-1}$ in 2018 . Maximum soil EC was recorded with $20 \mathrm{Mg} \mathrm{ha}^{-1} \mathrm{FYM}$ (1.90 and $\left.2.00 \mathrm{dS} \mathrm{m}^{-1}\right)$ and minimum with $10 \mathrm{Mg} \mathrm{ha}^{-1}$ FYM (1.70 
and $1.80 \mathrm{dS} \mathrm{m}^{-1}$ ) during 2017 and 2018, respectively. The treated plots had higher soil EC $\left(1.87 \mathrm{dS} \mathrm{m}^{-1}\right)$ than control plots $\left(1.62 \mathrm{dS} \mathrm{m}^{-1}\right)$. Regarding year and $\mathrm{BM}$ interaction, the greater differences in soil EC was noted in 2017 as compared to 2018, when the BM level increased from 25 to $50 \mathrm{~L} \mathrm{ha}^{-1}$ (Tables 2 and 3). The difference in EC values was $10 \mathrm{dS} \mathrm{m}^{-1}$ in 2017 and $9 \mathrm{dS} \mathrm{m}^{-1}$ in 2018 .

Soil mineral nitrogen $\left(N_{\text {min }}\right)$ content recorded at tasselling stage of maize was significantly higher (5\%) during 2018 as compared to 2017 (Tables 2 and 3). Similarly, doubling the amount of BM from 25 to $50 \mathrm{~L}$ ha $^{-1}$ the soil $\mathrm{N}_{\min }$ content significantly increased by $7.16 \%$ (2017) and 5.45\% (2018). Likewise, increasing the HA application from 3 to $9 \mathrm{~kg} \mathrm{ha}^{-1}$ the $\mathrm{N}_{\min }$ content increased from 29.70 to $34.00 \mathrm{mg} \mathrm{kg}^{-1}$ soil in 2017 and from 31.53 to $35.12 \mathrm{mg} \mathrm{kg}^{-1}$ soil in 2018 . Similarly, when the FYM level increased from 10 to $20 \mathrm{Mg} \mathrm{ha}^{-1}$, the soil $\mathrm{N}_{\min }$ content increased from 27.70 to $35.20 \mathrm{mg} \mathrm{kg}^{-1}$ soil in 2017 and from 29.00 to $37.50 \mathrm{mg} \mathrm{kg}^{-1}$ soil in 2018 showing an increase of $27 \%$ (2017) and 29\% (2018). The treated plots had higher soil $\mathrm{N}_{\text {min }}$ content (32.89 $\mathrm{mg} \mathrm{kg}^{-1}$ soil) compared to control plots $\left(22.12 \mathrm{mg} \mathrm{kg}^{-1}\right.$ soil). Interaction between $\mathrm{BM}$ and HA showed that increasing the HA level from 3 to 6 the $\mathrm{N}_{\min }$ availability sharply increased with $25 \mathrm{~L} \mathrm{ha}^{-1}$ $\mathrm{BM}$ as compared to $50 \mathrm{~L} \mathrm{ha}^{-1} \mathrm{BM}$, whereas with further increase in $\mathrm{HA}$ the increases in $\mathrm{N}_{\text {min }}$ availability were not sharp at both 25 and $50 \mathrm{~L} \mathrm{ha}^{-1} \mathrm{BM}$ applications (Table 2, Figure 5). Similarly, BM and FYM interaction showed that $\mathrm{N}_{\min }$ availability was higher with $50 \mathrm{~L} \mathrm{ha}^{-1}$ at high level $\left(20 \mathrm{Mg} \mathrm{ha}^{-1}\right)$ of FYM as compared to either lower level of FYM and/or with $25 \mathrm{~L} \mathrm{ha}^{-1} \mathrm{BM}$.

Soil total nitrogen $\left(N_{\text {tot }}\right)$ content decreased with increasing BM application (Tables 2 and 3). Both in 2017 and 2018 , the maximum soil $\mathrm{N}_{\text {tot }}$ content $(0.80$ and $0.80 \mathrm{~g} \mathrm{~kg}^{-1}$ soil) was observed with $25 \mathrm{~L} \mathrm{ha}^{-1} \mathrm{BM}$, and minimum (0.71 and $0.72 \mathrm{~g} \mathrm{~kg}^{-1}$ soil $)$ - with $50 \mathrm{~L} \mathrm{ha}^{-1} \mathrm{BM}$, respectively. This decrease was quantified as $12.68 \%$ and $11 \%$ in 2017 and 2018. Soil $\mathrm{N}_{\text {tot }}$ content decreased from 0.84 to $0.61 \mathrm{~g} \mathrm{~kg}^{-1}$ soil in 2017 and from 0.80 to $0.61 \mathrm{mg} \mathrm{kg}^{-1}$ soil in 2018 , when the HA level increased from 3 to $9 \mathrm{~kg} \mathrm{ha}^{-1}$, respectively. Unlikely, when the FYM increased from 10 to $20 \mathrm{Mg} \mathrm{ha}^{-1}$, the soil $\mathrm{N}_{\text {tot }}$ content also increased from 0.63 to $0.81 \mathrm{~g} \mathrm{~kg}^{-1}$ soil in 2017 and to 0.62 to $0.84 \mathrm{~g} \mathrm{~kg}^{-1}$ soil in 2018 . It was also noted that treated plots had higher soil $\mathrm{N}_{\text {tot }}$ content $\left(0.74 \mathrm{~g} \mathrm{~kg}^{-1}\right.$ soil) compared to control plots $\left(0.41 \mathrm{~g} \mathrm{~kg}^{-1}\right.$ soil $)$. The data regarding $\mathrm{BM}$ and $\mathrm{HA}$ interaction showed that the application of $25 \mathrm{~L} \mathrm{ha}^{-1} \mathrm{BM}$ had significantly higher soil $\mathrm{N}_{\text {tot }}$ content across the level of HA as compared to $50 \mathrm{~L} \mathrm{ha}^{-1} \mathrm{BM}$ application (Table 2, Figure 5). However, in the case of both levels of BM, the soil $\mathrm{N}_{\text {tot }}$ content significantly decreased with increasing the level of HA from 3 to $9 \mathrm{~kg} \mathrm{ha}^{-1}$. Similarly, the BM and FYM interaction showed that with the level of FYM increasing from 10 to $20 \mathrm{Mg} \mathrm{ha}^{-1}$ the soil $\mathrm{N}_{\text {tot }}$ content increased with both levels of BM application. However, the application of $25 \mathrm{~L} \mathrm{ha}^{-1} \mathrm{BM}$ had higher soil $\mathrm{N}_{\text {tot }}$ content across the level of FYM compared to $50 \mathrm{~L} \mathrm{ha}^{-1} \mathrm{BM}$ level.

Maize production in response to soil properties. The Pearson correlation analysis of different soil fertility indices and maize leaf area, grain yield and grain $\mathrm{N}$ content is provided in Figure 6.

It was observed that grain yield positively correlated with soil EC and $\mathrm{N}_{\min }$ and $\mathrm{N}_{\text {tot }}$ content. Similarly, leaf area showed positive correlation with

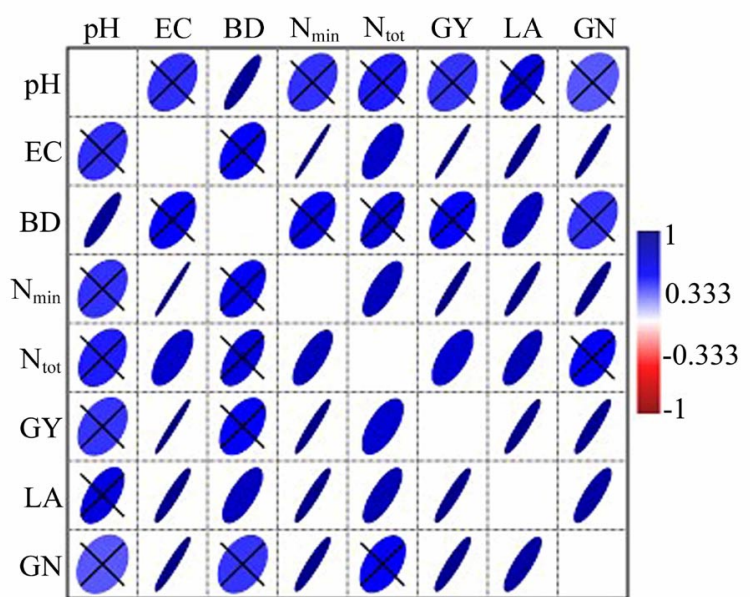

Note. GY - grain yield, LA - leaf area, GN - grain N; the crossed ellipse represents not significant correlations $(p \leq 0.05)$.

Figure 6. Correlation matrix of soil fertility variables: acidity $(\mathrm{pH})$, electrical conductivity (EC), bulk density (BD), mineral $\left(\mathrm{N}_{\min }\right)$ and total $\left(\mathrm{N}_{\text {tot }}\right)$ nitrogen content and maize plant parameters averaged of all treatments during 2017 and 2018

soil $\mathrm{EC}, \mathrm{BD}$ and $\mathrm{N}_{\min }$ and $\mathrm{N}_{\text {tot }}$ content. However, grain $\mathrm{N}$ uptake was positively correlated with soil EC and $\mathrm{N}_{\min }$ content. Among the soil fertility indices, significant positive correlations were observed among $\mathrm{pH}$ and $\mathrm{BD}$, EC with soil $\mathrm{N}_{\text {min }}$ and $\mathrm{N}_{\text {tot }}$ as well as $\mathrm{N}_{\text {min }}$ and $\mathrm{N}_{\text {tot }}$ content. Among these relationships, the relationship among the $\mathrm{N}_{\text {min }}$ content and $\mathrm{EC}$ was stronger than all other. Likewise, the maize grain yield was positively related to leaf area and grain $\mathrm{N}$ content.

\section{Discussion}

Phenological duration of maize. Days to tasselling, silking and physiological maturity in maize delayed with $50 \mathrm{~L} \mathrm{ha}^{-1}$ compared to $25 \mathrm{~L} \mathrm{ha}^{-1} \mathrm{BM}$. As a result of greater $\mathrm{N}_{\min }$ availability in response to greater decomposition of manure in the presence of microbes (Khan et al., 2019), the delayed tasselling and silking was associated with higher vegetative growth of maize (Khan et al., 2014). The increased $\mathrm{N}_{\text {min }}$ content is directly related to the increase in vegetative growth of maize (Khan et al., 2014); hence, the crop phenological events delayed. Other possible mechanisms could be the improved moisture availability (Wang et al., 2013), soil condition (Singh et al., 2015), crop stand (Ibrahim, Khan, 2017) and root elongation. These findings are in agreement with those of earlier researchers (Haji et al., 2014), who obtained delayed phenological events in maize due to microbe addition. Increasing HA application three times (from 3 to $9 \mathrm{~kg} \mathrm{ha}^{-1}$ ) delayed the physiological maturity of maize by 2 days. As a result of chelating properties of HA, the delayed physiological maturity could be related to the improved soil properties (Mackowiak et al., 2001). The chelating properties of HA had enhanced the nutrients availability, which might have enhanced the vegetative period, thus might have delayed the physiological maturity in maize crop.

The application of $20 \mathrm{Mg} \mathrm{ha}^{-1}$ FYM decreased days to emergence but increased days to tasselling, silking and physiological maturity of maize. The earlier emergence of maize might be associated with enhanced 
permeability of soil (Jat et al., 2019), water storage capacity of soil and optimized soil temperature (Wang et al., 2013). These results are in line with the findings of Khan et al. (2009), who reported earlier days to emergence of maize due to the application of FYM as compared to control plots. Similarly, when the higher amount of FYM was added, $\mathrm{N}_{\min }$ availability increased (Khan et al., 2019) as a result of increased decomposition of manure (Bowles et al., 2014). The direct addition of FYM is considered as addition of nutrients, which prolonged vegetative stage (Khan et al., 2014) and thus phenological events. The results agree with the data of Khan et al. (2009), who recorded delayed tasselling with $20 \mathrm{Mg} \mathrm{ha}^{-1}$ FYM.

Soil properties. The soil of the experimental site is low in SOM (Khan et al., 2019) thus providing FYM from external source provides a direct addition of nutrients (Khan et al., 2015). The BM increased the microbiological properties of soil (Odlare et al., 2008) and thus increased the decomposition of added manure (Ma et al., 2020). Similarly, the improvement in soil chelating properties by HA addition (Mackowiak et al., 2001) and the energy provision by FYM for microbes (Zhou et al., 2019) increased the nutrient availability (Khan et al., 2019), soil porosity and aeration (Guo et al., 2016) and soil health (Singh et al., 2015).

The lowering of soil $\mathrm{pH}$ from 8.0 to 7.7 with increasing FYM from 10 to $20 \mathrm{Mg} \mathrm{ha}^{-1}$ might be due to organic acid presence in FYM (Odlare et al., 2008), which released $\mathrm{H}^{+}$on mineralization or buffering capacity of manure (Whalen et al., 2000). The lowered soil BD in response to greater amount of BM, HA and FYM might be associated with improved soil biological properties (Odlare et al., 2008) as a result of BM application or chelating properties of HA (Mackowiak et al., 2001) and the energy provision by FYM for microbes (Zhou et al., 2019). The BM, HA and FYM increased the soil EC values but not above $2 \mathrm{dS} \mathrm{m}{ }^{-1}$. The increased EC is due to the total soluble material of soil solution (Behera, Shukla, 2015) and available nutrients (Khan et al., 2019) as a result of microbially mediated decomposition of manure (Luo et al., 2018).

$\boldsymbol{N}_{\text {min }}$ availability. The addition of FYM at a rate of $20 \mathrm{Mg} \mathrm{ha}^{-1}$ increased the soil $\mathrm{N}_{\text {tot }}(30 \%)$ and $\mathrm{N}_{\text {min }}$ (28\%) content compared with $10 \mathrm{Mg}^{\text {tot }} \mathrm{ha}^{-1} \mathrm{FYM}$. The increased $\mathrm{N}_{\text {tot }}$ content might be due to the direct SOM addition that hold true as adding $20 \mathrm{Mg} \mathrm{ha}^{-1} \mathrm{FYM}$ (having $0.86 \% \mathrm{~N})$ can theoretically add $170 \mathrm{~kg} \mathrm{ha}^{-1} \mathrm{~N}$. However, when BM was doubled and HA was tripled, the soil $\mathrm{N}_{\text {to }}$ content decreased by $12.7 \%$ and $34.4 \%$ with transformed increases in soil $\mathrm{N}_{\min }$ content by $6.1 \%$ and $12.9 \%$, respectively. It was also noted that HA application had a stronger impact on soil $\mathrm{N}_{\text {tot }}$ mineralization to $\mathrm{N}_{\text {min }}$ as compared to BM. This means that decreasing the soil $\mathrm{N}_{\text {tot }}$ content resulted in greater availability of $\mathrm{N}_{\min }$ as a result of FYM decomposition. This increases in soil $\mathrm{N}_{\min }$ content could be due to the fact that the soil of experimental site had lesser than 1\% SOM (Ibrahim et al., 2020). Thus, even if microbes are added, they need carbon as source of energy (Bello et al., 2020), whereas the addition of HA (containing 30\% SOC) provided carbon as source of energy (Mackowiak et al., 2001), and mineralization of soil $\mathrm{N}_{\text {tot }}$ increased the soil $\mathrm{N}_{\text {min }}$ availability. Increasing HA and BM levels improved the soil microbial activities (Bowles et al., 2014) that increased the soil $\mathrm{N}_{\min }$ content and decreased the soil $\mathrm{N}_{\text {tot }}$.
The current studies for improving soil $\mathrm{N}_{\text {min }}$ content could be related to a direct source of microbes improving the function of microbe by adding $\mathrm{HA}$ and a direct addition of FYM as a nutrient source. The increased soil $\mathrm{N}_{\min }$ content might be due to increased residual effect of manure, improved moisture holding capacity and regulated temperature (Wang et al., 2013) as well as other physico-chemical properties of soil (Odlare et al., 2008). The results of our experiment are in agreement with the findings of earlier researchers (Muhammad et al., 2018; Khan et al., 2019).

\section{Conclusions}

1. Doubling the beneficial microbes $(\mathrm{BM})$ amount delayed the maize phenological events (by 2 to 5 days) and improved soil mineral nitrogen $\left(\mathrm{N}_{\min }\right)$ content $(6.30 \%)$; however, the soil total nitrogen $\left(\mathrm{N}_{\text {tot }}\right)$ content decreased by $12.7 \%$. The addition of humic acid (HA) had positive effect on $\mathrm{N}_{\text {min }}$ availability and delayed phenological observations. Similarly, increasing the farmyard manure (FYM) level from 10 to $20 \mathrm{Mg} \mathrm{ha}^{-1}$ the phenological observations delayed except for days to emergence.

2. Under both levels of $B M$, the soil $\mathrm{N}_{\text {mi }}$ availability increased but soil $\mathrm{N}_{\text {tot }}$ content decreased with increasing HA and FYM levels.

3. Grain yield was positively correlated with soil $\mathrm{EC}, \mathrm{N}_{\min }$ and $\mathrm{N}_{\text {tot }}$ content, whereas leaf area was positively correlated with soil EC, BD, $\mathrm{N}_{\text {min }}$ and $\mathrm{N}_{\text {tot }}$ content. However, grain $\mathrm{N}$ uptake was positively correlated with soil $\mathrm{EC}$ and $\mathrm{N}_{\min }$ content.

Received 05012021

Accepted 18072021

\section{References}

Behera S. K., Shukla A. K. 2015. Spatial distribution of surface soil acidity, electrical conductivity, soil organic carbon content and exchangeable potassium, calcium and magnesium in some cropped acid soils of India. Land Degradation and Development, 26: 71-79. https://doi.org/10.1002/ldr.2306

Bello A., Han Y., Zhu H., Deng L., Yang W., Meng Q., Sun Y., Egbeagu U. U., Sheng S., Wu X., Jiang X., Xu X. 2020. Microbial community composition, co-occurrence network pattern and nitrogen transformation genera response to biochar addition in cattle manure-maize straw composting. Science of the Total Environment, 721: 137759. https://doi.org/10.1016/j.scitotenv.2020.137759

Bharali A., Baruah K. K., Bhattacharyya P., Gorh D. 2017. Integrated nutrient management in wheat grown in a northeast India soil: impacts on soil organic carbon fractions in relation to grain yield. Soil and Tillage Research, 168: 81-91. https://doi.org/10.1016/j.still.2016.12.001

Bhattacharyya R., Chandra S., Singh R., Kundu S., Srivastva A., Gupta H. 2007. Long-term farmyard manure application effects on properties of a silty clay loam soil under irrigated wheat-soybean rotation. Soil and Tillage Research, 94: 386-396. https://doi.org/10.1016/j.still.2006.08.014

Bowles T. M., Acosta-Martínez V., Calderón F., Jackson L. E. 2014. Soil enzyme activities, microbial communities, and carbon and nitrogen availability in organic agroecosystems across an intensively-managed agricultural landscape. Soil Biology and Biochemistry, 68: 252-262. https://doi.org/10.1016/j.soilbio.2013.10.004 
Brannon C. A., Sommers L. E. 1985. Preparation and characterization of model humic polymers containing organic phosphorus. Soil Biology and Biochemistry, 17: 213-219. https://doi.org/10.1016/0038-0717(85)90117-8

Bremner J. M., Mulvaney C. S. 1983. Nitrogen-total. Page A. L. (ed.). Methods of Soil Analysis. Part 2. Chemical and Microbiological Properties, chapter 31, p. 595-624. https://doi.org/10.2134/agronmonogr9.2.2ed.c31

Cabilovski R., Manojlovic M., Bogdanovic D., Magazin N., Keserovic Z., Sitaula B. K. 2014. Mulch type and application of manure and composts in strawberry (Fragaria $\times$ ananassa Duch.) production: impact on soil fertility and yield. Zemdirbyste-Agriculture, 101 (1): 67-74. https://doi.org/10.13080/z-a.2014.101.009

Guo L., Wu G., Li Y., Li C., Liu W., Meng J., Liu H., Yu X., Jiang G. 2016. Effects of cattle manure compost combined with chemical fertilizer on topsoil organic matter, bulk density and earthworm activity in a wheat-maize rotation system in Eastern China. Soil and Tillage Research, 156: 140-147. https://doi.org/10.1016/j.still.2015.10.010

Hai S. M. A., Mir S. 1998. The lignitic coal derived humic acid and the prospective utilization in Pakistan's agriculture and industry. Science Technology and Development, 17 (3): 32-40. https://inis.iaea.org/search/search.aspx?orig $\mathrm{q}=\mathrm{RN}: 30031177$

Haji M., Zaman A., Khalil S. K., Shah Z. 2014. Effect of beneficial microbes $(\mathrm{BM})$ on the efficiency of organic and inorganic $\mathrm{N}$ fertilizers on wheat crop. Sarhad Journal of Agriculture, 30 (1): 7-13. https://www.aup.edu.pk/sj pdf/2\%20264-2012.pdf

Ibrahim M., Khan A. 2017. Phenology and maize crop stand in response to mulching and nitrogen management. Sarhad Journal of Agriculture, 33 (3): 426-434. https://doi.org/10.17582/journal.sja/2017/33.3.426.434

Ibrahim M., Khan A., Ali W., Akbar H. 2020. Mulching techniques: an approach for offsetting soil moisture deficit and enhancing manure mineralization during maize cultivation. Soil and Tillage Research, 200: 104631. https://doi.org/10.1016/j.still.2020.104631

Jan M. T., Shah P., Hollington P. A., Khan M. J., Sohail Q. 2009. Agriculture research: design and analysis: a monograph. The Univesity of Agriculture, Peshawar, Pakistan, p. 41-50.

Jat S. L., Parihar C. M., Singh A. K., Nayak H. S., Meena B. R., Kumar B., Parihar M. D., Jat M. L. 2019. Differential response from nitrogen sources with and without residue management under conservation agriculture on crop yields, water-use and economics in maize-based rotations. Field Crops Research, 236: 96-110. https://doi.org/10.1016/j.fcr.2019.03.017

Jiang Y., Yan J. 2010. Effects of land use on hydrochemistry and contamination of karst groundwater from nandong underground river system, China. Water, Air, and Soil Pollution, 210: 123-141. https://doi.org/10.1007/s11270-009-0229-z

Keeney D. R., Nelson D. W. 1983. Nitrogen-inorganic form. Page A. L. (ed.). Methods of Soil Analysis. Part 2. Chemical and Microbiological Properties, chapter 33, p. 643-698. https://doi.org/10.2134/agronmonogr9.2.2ed.c33

Khan A., Jan M. T., Marwat K. B., Arif M. 2009. Organic and inorganic nitrogen treatments effects on plant and yield attributes of maize in a different tillage systems. Pakistan Journal of Botany, 41 (1): 99-108. http://www.pakbs.org/ pjbot/PDFs/41(1)/PJB41(1)099.pdf

Khan A., Jan M. T., Jan A., Shah Z., Arif M. 2014. Efficiency of dry matter and nitrogen accumulation and redistribution in wheat as affected by tillage and nitrogen management. Journal of Plant Nutrition, 37: 723-737. https://doi.org/10.1080/01904167.2013.867989
Khan A., Jan M. T., Afzal M., Muhammad I., Jan A., Shah Z. 2015. An integrated approach using organic amendments under a range of tillage practices to improve wheat productivity in a cereal based cropping system. International Journal of Agriculture and Biology, 17: 467-474. https://doi.org/10.17957/IJAB/17.3.13.248

Khan A., Afridi M. Z., Airf M., Ali S., Muhammad I. 2017. A sustainable approach toward maize production: effectiveness of farm yad manure and urea N. Annals of Biological Sciences, 5 (1): 8-13. https://doi.org/10.21767/2348-1927.1000103

Khan A., Ali N., Haider S. I. 2018. Maize productivity and soil carbon storage as influenced by wheat residue management. Journal of Plant Nutrition, 41: 1868-1878. https://doi.org/10.1080/01904167.2018.1463384

Khan A., Fahad S., Khan A., Saud S., Adnan M., Wahid F., Noor M., Nasim W., Hammad H. M., Bakhat H. F., Ahmad S., Habibur Rehman M., Wang D., Sönmez O. 2019. Managing tillage operation and manure to restore soil carbon stocks in wheat-maize cropping system. Agronomy Journal, 111: 2600-2609. https://doi.org/10.2134/agronj2019.02.0100

Khattak R., Muhammad D. 2008. Increasing crop production through humic acid in salt affected soils in Kohat division (NWFP). Pak-Us Collaborative Research Endeavor, ALP Project, Pakistan Agriculture Research Council, Islamabad.

Kurepin L. V., Zaman M., Pharis R. P. 2014. Phytohormonal basis for the plant growth promoting action of naturally occurring biostimulators. Journal of the Science of Food and Agriculture, 94 (9): 1715-1722. https://doi.org/10.1002/jsfa.6545

Luo G., Li L., Friman V.-P., Guo J., Guo S., Shen Q., Ling N. 2018. Organic amendments increase crop yields by improving microbe-mediated soil functioning of agroecosystems: a meta-analysis. Soil Biology and Biochemistry, 124: 105-115. https://doi.org/10.1016/j.soilbio.2018.06.002

Ma Q., Wen Y., Ma J., Macdonald A., Hill P. W., Chadwick D. R., Wu L., Jones D. L. 2020. Long-term farmyard manure application affects soil organic phosphorus cycling: a combined metagenomic and ${ }^{33} \mathrm{P} /{ }^{14} \mathrm{C}$ labelling study. Soil Biology and Biochemistry, 149: 107959. https://doi.org/10.1016/j.soilbio.2020.107959

Mackowiak C., Grossl P., Bugbee B. 2001. Beneficial effects of humic acid on micronutrient availability to wheat. Soil Science Society of America Journal, 65: 1744-1750. https://doi.org/10.2136/sssaj2001.1744

Mclean E. O. 1983. Soil pH and lime requirement. Page A. L. (ed.). Methods of Soil Analysis. Part 2. Chemical and Microbiological Properties, chapter 12, p. 199-224. https://doi.org/10.2134/agronmonogr9.2.2ed.c12

Muhammad I., Khan F., Khan A., Wang J. 2018. Soil fertility in response to urea and farmyard manure incorporation under different tillage systems in Peshawar, Pakistan. International Journal of Agriculture and Biology, 20: 15391547. https://www.fspublishers.org/Issue.php?y=2018\&v no $=20 \&$ category $\mathrm{ID}=156$

Odlare M., Pell M., Svensson K. 2008. Changes in soil chemical and microbiological properties during 4 years of application of various organic residues. Waste Management, 28: $1246-1253$. https://doi.org/10.1016/j.wasman.2007.06.005

Rhoades J. D. 1996. Salinity: electrical conductivity and total dissolved solids. Spaks D. L. et al. (eds). Methods of Soil Analysis. Part 3. Chemical Methods, chapter 14, p. 417-435. https://doi.org/10.2136/sssabookser5.3.c14 
Satyanarayana V., Vara Prasad P., Murthy V., Boote K. 2002. Influence of integrated use of farmyard manure and inorganic fertilizers on yield and yield components of irrigated lowland rice. Journal of Plant Nutrition, 25: 2081-2090.

https://doi.org/10.1081/PLN-120014062

Singh B. B., Singh J., Singh G., Kaur G. 2015. Effects of long term application of inorganic and organic fertilizers on soil organic carbon and physical properties in maize-wheat rotation. Agronomy, 5: 220-238.

https://doi.org/10.3390/agronomy5020220

Soil Survey of Pakistan. 2007. Land resource inventory and agricultural land use plan of Peshawar district. National agricultural land use plan. Lahore, Pakistan. https:// urbanpolicyunit.gkp.pk/wp-content/uploads/2018/03/ Final-Peshawar-Landuse-Report-2017.pdf
Wang J. X., Jia Z. K., Liang L. Y., Kang S. Z. 2013. Effect of manure management on the temporal variations of dryland soil moisture and water use efficiency of maize. Journal of Agriculture Science and Technology 15: 1293-1304. https://jast.modares.ac.ir/article-23-6266-en.pdf

Whalen J. K., Chang C., Clayton G. W., Carefoot J. P. 2000. Cattle manure amendments can increase the $\mathrm{pH}$ of acid soils. Soil Science Society of America Journal, 64: 962-966. https://doi.org/10.2136/sssaj2000.643962x

WRB. 2014. World reference base for soil resources. World Soil Sources Report No. 106. http://www.fao.org/3/i3794en/ I3794en.pdf

Zhou G., Qiu X., Zhang J., Tao C. 2019. Effects of seaweed fertilizer on enzyme activities, metabolic characteristics, and bacterial communities during maize straw composting. Bioresource Technology, 286: 121375.

https://doi.org/10.1016/j.biortech.2019.121375

\title{
Kukurūzų reakcija ị dẻl naudingųjų mikroorganizmų, huminių rūgščiu ir tręšimo mėšlu pagerẻjusias dirvožemio savybes
}

\author{
I. Hussain, A. Khan, H. Akbar, Z. Hussain \\ Pešavaro žemès ūkio universitetas, Pakistanas
}

\section{Santrauka}

Siekiant išvengti aplinkos taršos, dvejų metų (2017 ir 2018 m.) lauko eksperimento metu buvo vertintas gyvulių mėšlo naudojimas kartu su naudingaisiais mikroorganizmais (NM): 25 ir $50 \mathrm{~L}^{-1}{ }^{-1}$, huminėmis rūgštimis (HR): 3,6 ir $9 \mathrm{~kg} \mathrm{ha}^{-1}$, ir gyvulių méšlu (GM): 10, 15 ir $20 \mathrm{Mg} \mathrm{ha}^{-1}$, palyginus su kontroliniu variantu be šių priedų. Naudingųjų mikroorganizmų kiekị padidinus nuo 25 iki $50 \mathrm{~L} \mathrm{ha}^{-1}$, paprastojo kukurūzo (Zea mays L.) fenologiniai reiškiniai paankstėjo viena diena, dirvožemyje sumažèjo suminio azoto $\left(\mathrm{N}_{\text {sum }}\right)$ kiekis $(12,6 \%)$, tačiau pagerèjo dirvožemio tankis $\left(1,89 \mathrm{Mg} \mathrm{m}^{-3}\right)$, elektrinis laidumas $\left(1,90 \mathrm{dS} \mathrm{m}^{-1}\right)$ ir mineralinio $\mathrm{N}\left(\mathrm{N}_{\text {min }}\right)$ kiekis $\left(33,89 \mathrm{mg} \mathrm{kg}^{-1}\right.$ dirvožemio). Huminių rūgščių kieki padidinus nuo 3 iki $9 \mathrm{~kg} \mathrm{ha}^{-1}$, kukurūzų fiziologinè branda pailgèjo dviem dienomis, tačiau padidejo dirvožemio elektrinis laidumas $\left(0,11 \mathrm{dS} \mathrm{m}^{-1}\right)$, dirvožemio tankis $(1,63 \%), \mathrm{N}_{\text {min }}(12,94 \%)$ ir sumažèjo $\mathrm{N}_{\text {sum }}(34,42 \%)$ kiekis dirvožemyje. Gyvulių měšlo kieki padidinus nuo $10 \mathrm{iki} 20 \mathrm{Mg} \mathrm{ha}^{-1}$, fenologiniai reiškiniai vèlavo, tačiau pagerèjo dirvožemio savybès, t. y. pH (-0,3 vieneto), EC $(6,66 \%)$, dirvožemio tankis $(-5,83 \%)$, $\mathrm{N}_{\text {min }}(28,14 \%)$ ir $\mathrm{N}_{\text {sum }}(30,16 \%)$ kiekis. Dirvožemio elektrinis laidumas ir $\mathrm{N}_{\text {sum }}$ bei $\mathrm{N}_{\text {min }}$ kiekis reikšmingai teigiamai koreliavo su kukurūzų lapų plotu, N kiekiu grūduose ir grūdų derliumi. Padaryta išvada, kad pridejjus $50 \mathrm{~L}^{\text {ha }}{ }^{-1}$ NM arba 6-9 kg ha-1 HR, padidejjo gyvulių měšlo mineralizacija, pailgèjo kukurūzų augimo laikotarpis ir pagerėjo dirvožemio derlingumo rodikliai.

Taigi, siekiant pagerinti $\mathrm{N}_{\min }$ pasisavinimą, pailginti kukurūzų fenologinę trukmę ir padidinti derlingumą, $20 \mathrm{Mg} \mathrm{ha}^{-1} \mathrm{GM}$ reikètų naudoti kartu su $50 \mathrm{~L} \mathrm{ha}^{-1} \mathrm{NM}$ ir/ar $6 \mathrm{~kg} \mathrm{ha}^{-1} \mathrm{HR}$.

Reikšminiai žodžiai: dirvožemio savybès, kukurūzų fenologija, mineralinis azotas, skaidymas. 